Dikirim: 14 Juni 2016 Diterbitkan: 1 Maret 2017

\section{Determinan perilaku tes HIV ibu hamil di puskesmas Bandarharjo kota Semarang}

\section{Determinants of HIV testing behavior among pregnant women in} public health center Bandarharjo Semarang

Rany Ekawati ${ }^{1}$, Yanri Wijayanti ${ }^{2}$, Mohammad Hakimi ${ }^{1}$

\begin{abstract}
Purpose: This research aimed to determine factors associated with HIV testing behavior among pregnant women at the public health center Bandarharjo Semarang. Methods: This research was a descriptive analytic observational study with a matched case control design. Samples were pregnant women at the health center in Bandarharjo Semarang who have been offered an HIV test totaling 90 samples. Samples in the control group were matched according to trimester age of pregnancy to the case group with ratio of 1:1. Samples were enlisted by consecutive sampling. The research instrument used was a questionnaire. The data analysis consisted of univariable, bivariable comparisons using the McNemar test, and multivariable using conditional logistic regression tests. Results: No significant correlations were found, but practical information about HIV (OR 2.35; CI95\% 0.801-6.9) and stigma (OR 2.16; CI95\% 0.722-6.479) were related to HIV testing behavior. Conclusion: Practical information about HIV and stigma are correlated to HIV testing behavior.
\end{abstract}

Keywords: HIV testing; pregnant women; matched case control

\footnotetext{
${ }^{1}$ Departemen Biostatistik, Epidemiologi dan Kesehatan Populasi, Fakultas Kedokteran, Universitas Gadjah Mada (Email: ranyekawati@gmail.com)

${ }^{2}$ Departemen Ilmu Penyakit Dalam, Fakultas Kedokteran, Universitas Gadjah Mada
} 


\section{PENDAHULUAN}

Infeksi HIV pada ibu hamil mengancam kehidupan ibu dan menularkan virus kepada bayi. Lebih dari 90\% anak terinfeksi HIV merupakan proses penularan dari ibu ke anak (1). Pada tahun 2013, sebesar 54\% ibu hamil di negara miskin tidak memperoleh tes HIV untuk pencegahan, pengobatan, perawatan HIV (2). Penelitian kepada ibu hamil menunjukkan pengetahuan tentang HIV, stigmatisasi, dan motivasi masih kurang menjadi penyebab tidak melakukan tes HIV $(3,4,5)$. Hambatan lain berupa dukungan suami, takut ditolak masyarakat, dan takut hasil tes HIV positif $(6,7)$. Jumlah kumulatif kasus HIV/AIDS di Jawa Tengah sejak tahun 1993 sampai dengan September 2014 tertinggi pada kota Semarang dengan jumlah AIDS sebanyak 453 kasus dan HIV sebanyak 1.001 kasus (8). Kota Semarang berada pada epidemi terkonsentrasi. Semua ibu hamil wajib ditawari tes HIV sebagai pemeriksaan laboratorium rutin saat pemeriksaan antenatal atau menjelang persalinan (9). Laporan surveilans HIV/AIDS kota Semarang tahun 2011 sampai 2014 jumlah kasus HIV dan AIDS di puskesmas Bandarharjo sebanyak 44 kasus dan menjadi tertinggi (10). Puskesmas Bandarharjo melaporkan sebanyak 3,7\% (73 ibu) ibu hamil melakukan tes HIV dari jumlah ibu hamil yang ditawari tes HIV (1.987 ibu) yang termasuk angka paling kecil dibandingkan puskemas lain (11). Penelitian ini bertujuan untuk mengetahui faktor yang berpengaruh terhadap perilaku tes HIV pada ibu hamil.

\section{METODE}

Studi matched case control melibatkan ibu hamil yang mengikuti kunjungan antenatal di puskesmas Bandarharjo kota Semarang dan sudah ditawari tes HIV sebanyak 90 sampel. Sampel kelompok kontrol di match sesuai umur trimester kehamilan pada kelompok kasus dengan perbandingan 1:1. Sampel diambil dengan consecutive sampling. Variabel bebas adalah pendidikan, pekerjaan, status perkawinan, umur, informasi, pengetahuan HIV/AIDS, stigma HIV/AIDS, akses ke pelayanan kesehatan, jumlah kehamilan, dukungan suami, dan dukungan tenaga kesehatan. Variabel terikat adalah perilaku tes HIV. Instrumen penelitian menggunakan kuesioner. Analisis univariabel untuk melihat distribusi dan frekuensi variabel penelitian. Analisis bivariabel menghasilkan nilai OR dan CI 95\%. Analisis multivariabel dengan conditional logistic regression. Penelitian ini telah mendapatkan etika penelitian dari Komisi Etik Penelitian Fakultas Kedokteran Universitas Gadjah Mada.

\section{HASIL}

Sebagian besar pendidikan responden dan suami dari pendidikan tinggi. Pekerjaan ibu pada kelompok kasus dan kontrol terbanyak dari tidak bekerja. Status pekerjaan seluruh suami bekerja. Sebagian besar umur ibu pada kelompok kasus dan kontrol termasuk tidak berisiko tinggi untuk kehamilan. Responden kelompok kasus lebih banyak mengetahui informasi tentang HIV daripada kelompok kontrol. Responden yang berpengetahuan tinggi pada kasus lebih rendah dibandingkan kelompok kontrol. Stigma HIV yang tinggi pada kelompok kasus lebih rendah dibandingkan dengan kelompok kontrol. Jumlah kehamilan multigravida kelompok kasus lebih tinggi dibandingkan kelompok kontrol. Akses ke layanan kesehatan relatif mudah dijangkau baik pada kelompok kasus maupun kontrol. Dukungan suami sama antara kelompok kasus dan kontrol. Dukungan tenaga kesehatan lebih tinggi pada kelompok kasus daripada kelompok kontrol (Tabel 1).

Tabel 1. Ciri responden kelompok kasus dan kontrol

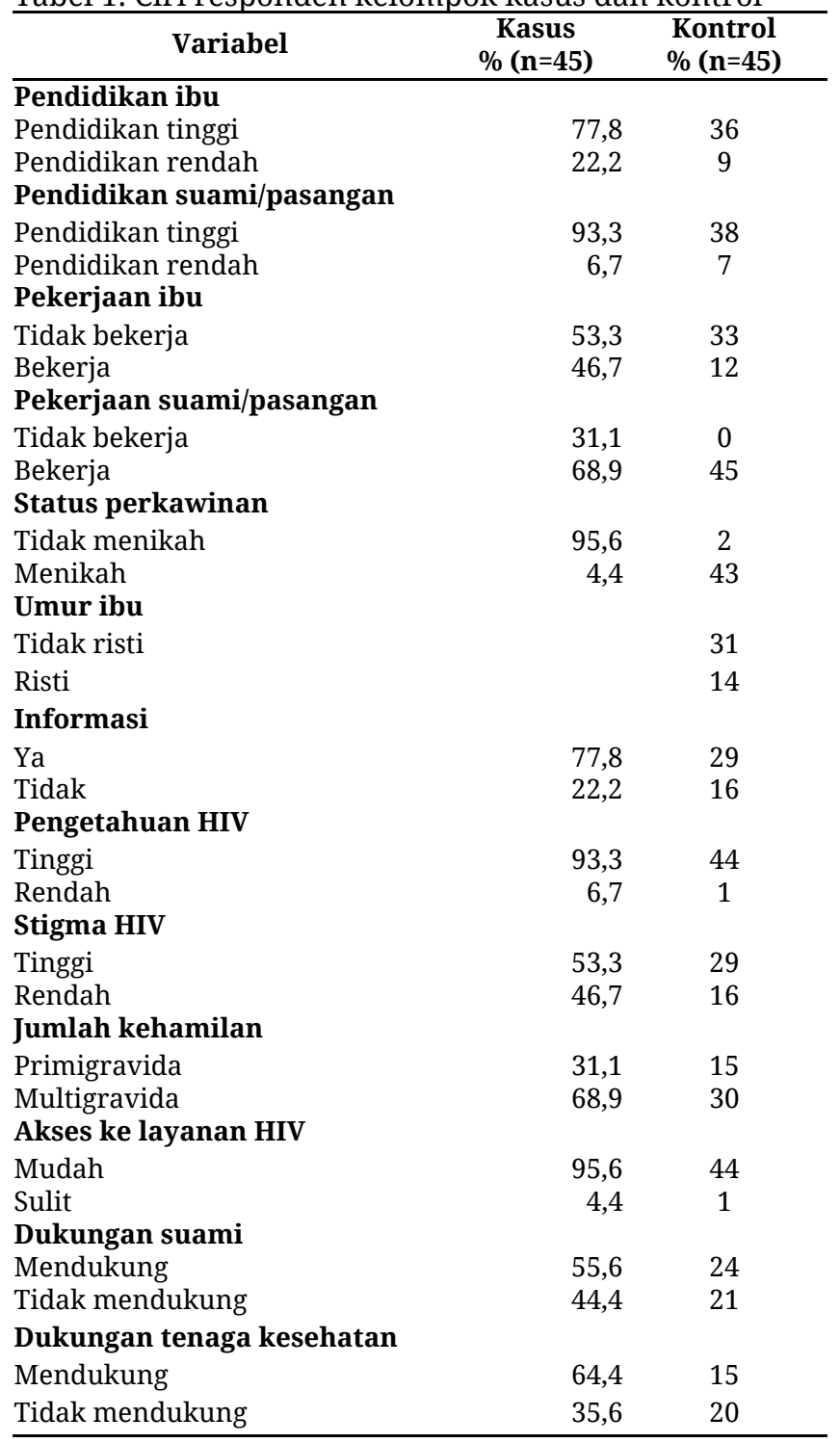


Pekerjaan ibu, status perkawinan, umur ibu, informasi, stigma HIV, dan dukungan tenaga kesehatan menunjukkan bahwa OR kurang dari 1,5 sehingga dapat dimaknai secara praktis. Berdasarkan nilai p, tidak ada variabel yang signifikan berpengaruh dengan perilaku tes HIV ( $p>0,05)$.

Tabel 2. Faktor yang memengaruhi perilaku tes HIV ibu hamil

\begin{tabular}{lcccc}
\hline \multicolumn{1}{c}{ Variabel } & $\mathbf{x}^{2}$ & OR & CI 95\% & Nilai p \\
\hline Pendidikan ibu & 0,29 & 1,33 & $0,405-4,662$ & 0,593 \\
Pekerjaan ibu & 1 & 1,66 & $0,548-5,579$ & 0,317 \\
Pendidikan suami/pasangan & 1,14 & 0,55 & $0,146-1,845$ & 0,285 \\
Status Perkawinan & 1 & 3 & $0,241-157,4$ & 0,317 \\
Umur ibu & 1 & 2 & $0,427-12,359$ & 0,317 \\
Informasi & 2,25 & 2,2 & $0,704-8,076$ & 0,133 \\
Pengetahuan HIV & 1 & 0,333 & $0,006-4,151$ & 0,317 \\
Stigma HIV & 1,67 & 2 & $0,622-7,457$ & 0,196 \\
Jumlah kehamilan & 0,04 & 0,916 & $0,366-2,269$ & 0,834 \\
Akses ke layanan HIV & 0,33 & 0,5 & $0,008-9,604$ & 0,563 \\
Dukungan suami & 0,06 & 0,888 & $0,298-2,595$ & 0,808 \\
Dukungan tenaga kesehatan & 1,14 & 1,8 & $0,541-6,837$ & 0,285 \\
\hline
\end{tabular}

\section{BAHASAN}

Pendidikan tidak berpengaruh terhadap perilaku tes HIV karena tawaran tenaga kesehatan untuk tes HIV memungkinkan seseorang berpendidikan rendah maupun tinggi untuk melakukan tes HIV. Hasil berbeda dengan penelitian Moges dan Amberbir yang menyatakan bahwa status pendidikan termasuk faktor penting kesediaan ibu hamil untuk melakukan tes HIV (4). Ibu tidak bekerja mempunyai kesempatan waktu lebih banyak untuk datang ke puskesmas untuk melakukan tes HIV dibandingkan ibu yang bekerja. Umur ibu yang tidak berisiko tinggi siap hamil dan bersedia kontrol kehamilan, termasuk untuk melakukan tes HIV. Ibu dengan umur lebih dewasa mampu mengambil keputusan sendiri (12). Perempuan yang menikah cenderung membahas isu konseling HIV dan tes sukarela kepada suami, me- mutuskan apakah akan diuji atau tidak, dan lebih percaya diri bahwa mereka berada pada risiko yang lebih kecil dibandingkan dengan yang belum meni- kah karena komitmen pernikahan (13). Pengetahuan mempunyai tahapan yang meliputi tahu, memahami, aplikasi, analisis, sintesis dan evaluasi (14). Tingkat pengetahuan responden kemungkinan masih dalam tahap belum berperilaku. Stigma HIV berpengaruh terhadap keinginan untuk tes HIV yang masih kurang, mendapatkan tes rutin, dan perencanaan untuk tes pada responden yang belum pernah melakukan tes. Responden yang memiliki stigma dan ketakutan lebih tinggi kurang mendapatkan informasi tentang tes HIV (15). Jumlah kehamilan tidak berpengaruh dengan perilaku tes HIV karena tawaran dari tenaga kesehatan untuk tes HIV, sehingga primigravida dan multigravida dapat melakukan tes HIV. Program dinas kesehatan kota Semarang, semua ibu hamil harus tes HIV dan tidak dipungut biaya. Tidak ada hubungan antara akses layanan dengan perilaku tes HIV karena letak puskesmas terjangkau. Dukungan suami tidak berpengaruh terhadap perilaku tes HIV karena tawaran dari tenaga kesehatan saat pemeriksaan kehamilan. Dukungan tenaga kesehatan meliputi pemberian informasi, pemberian nasihat, petunjukpetunjuk, saran-saran, informasi atau umpan balik (18).

\section{SIMPULAN}

Tidak terdapat hubungan yang signifikan antara variabel dengan perilaku tes HIV, namun informasi dan stigma HIV secara praktis berpengaruh dengan perilaku tes HIV. Puskesmas bersama stakeholder agar meningkatkan pemahaman ibu hamil untuk melakukan tes HIV pada saat hamil. Peran tenaga kesehatan untuk meningkatkan dukungan terutama waktu yang ditentukan untuk tes HIV tidak hanya saat kunjungan antenatal tetapi setiap hari kerja.

\section{Abstrak}

Tujuan: Studi ini bertujuan untuk mengetahui faktor yang berpengaruh terhadap perilaku tes HIV pada ibu hamil. Metode: Studi matched case control melibatkan ibu hamil pada kunjungan antenatal di puskesmas Bandarharjo Semarang yang ditawari tes HIV, sebanyak 90 sampel. Sampel kelompok kontrol sesuai umur trimester kehamilan kelompok kasus dengan perbandingan 1:1. Sampel diambil melalui consecutive sampling. Instrumen menggunakan kuesioner. Analisis data menggunakan analisis univariat, bivariat dengan McNemar dan multivariat melalui conditional logistic regression. Hasil: Penelitian menunjukkan tidak ada hubungan signifikan, tetapi secara praktis variabel informasi 
HIV (OR 2,35; CI95\% 0,801-6,9) dan stigma (OR 2,16; CI95\% 0,722-6,479) berpengaruh terhadap perilaku tes HIV. Simpulan: Informasi tentang HIV dan stigma berpengaruh terhadap perilaku tes HIV.

Kata kunci: tes HIV; ibu hamil; matched case control

\section{PUSTAKA}

1. Kementerian Kesehatan. Pedoman Nasional Pencegahan Penularan HIV dari Ibu Ke Anak (PPIA). Jakarta. 2012.

2. United Nations Programme on HIV/AIDS. The Gap Report 2014: Children and Pregnant Women Living with HIV. 2014.

3. Ali AA, Osman E. Factors Influencing HIV Voluntary Counseling and Testing (Vct) Among Pregnant Women in Kassala, Eastern Sudan. J Women's Health Care. 2014;3(198):2167-0420.

4. Moges Z, Amberbir A. Factors associated with readiness to VCT service utilization among pregnant women attending antenatal clinics in Northwestern Ethiopia: a health belief model approach. Ethiopian journal of health sciences. 2011 Aug;21(Suppl 1):107.

5. Turan JM, Bukusi EA, Onono M, Holzemer WL, Miller S, Cohen CR. HIV/AIDS stigma and refusal of HIV testing among pregnant women in rural Kenya: results from the MAMAS Study. AIDS and Behavior. 2011 Aug 1;15(6):1111-20.

6. Fanta W, Worku A. Determinants for refusal of HIV testing among women attending for antenatal care in Gambella Region, Ethiopia. Reproductive health. 2012 Jul 26;9(1):8.

7. Belachew A, Mariam AG. Factors affecting acceptance of HIV counseling \& testing among antenatal care attendants: with emphasis on role of male partners. International Journal of Scientific \& Engineering Research. 2012;3(4):1-11.

8. Komisi Penanggulangan AIDS Provinsi Jawa Tengah. Data HIV dan AIDS Provinsi Jawa Tengah. 2014.

9. Peraturan Menteri Kesehatan Republik Indonesia nomor 21 tahun 2013 tentang Penanggulangan HIV dan AIDS. 2013.

10. Dinas Kesehatan Kota Semarang. Data Kasus HIV dan AIDS Kota Semarang berdasarkan Laporan Surveilans HIV dan AIDS Tahun 2011-2014. Semarang: 2014.

11. Dinas Kesehatan Kota Semarang. Rekapan PPIA Tahun 2014. Semarang. 2014.

12. Idris AK, Elsamani EZ, Elnasri AE. Sociodemographic predictors of acceptance of voluntary HIV testing among pregnant women in a large maternity hospital, Omdurman, Sudan/Facteurs sociodemographiques predictifs de l'acceptation d'un depistage volontaire du VIH chez des femmes enceintes dans une grande maternite hospitaliere a Omdurman (Soudan). Eastern Mediterranean Health Journal. 2015 Apr 1;21(4):273.

13. Worku G, Enquselassie F. Factors determining acceptance of voluntary HIV counseling and testing among pregnant women attending antenatal clinic at army hospitals in Addis Ababa. Ethiopian medical journal. 2007 Jan;45(1):1-8.

14. Notoatmodjo S. Promosi Kesehatan dan Ilmu Perilaku. Jakarta: Rineka Cipta. 2007.

15. Weiser SD, Heisler M, Leiter K, Percy-de Korte F, Tlou S, DeMonner S, Phaladze N, Bangsberg DR, Iacopino V. Routine HIV testing in Botswana: a population-based study on attitudes, practices, and human rights concerns. PLoS medicine. 2006 Jul 18;3(7):e261. 